ELORE (ISSN 1456-3010), vol. $12-2 / 2005$.

Julkaisija: Suomen Kansantietouden Tutkijain Seura ry. Taitto: Jukka Talve \& Outi Fingerroos.

[http://cc.joensuu.fi/ loristi/2_05/szs2_05.pdf]

\title{
ETELÄPOHJALAISUUDEN TUOTTAMINEN SOSIOEMOTIONAALISESSA SÄHKÖPOSTIVIESTINNÄSSÄ
}

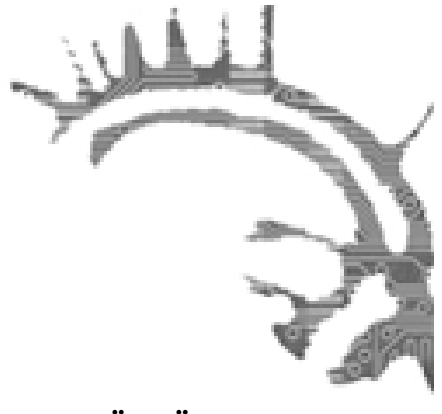

Kari Salo, Kaj Zimmerbauer, Timo Suutari

Sähköposti on internetin suosituimpia, vakiintuneimpia ja arkipäiväisimpiä digitaalisen viestinnän sovelluksia. Internetin muiden sovellusten ohella sähköposti on sekä korvannut että täydentänyt aikaisempia viestinnän muotoja. Sähköposti ja internet ovat kuitenkin verrattain tuoreita viestintävälineitä, ja niiden käytön nopea lisääntyminen on aiheuttanut jännitteitä ja vaatimuksia aiemmille viestinnän luokituksille, määrityksille ja säännöille. Aiemmat käsitteellistämistavat eivät välttämättä toimi uusien viestinten kanssa.

Sähkeöpostiviestinnässä viestijä pääsee huomattavan vähin ponnistuksin laajaan levitykseen etenkin, kun sitä verrataan aiempiin viestinnän keinoihin. Kiusaus liialliseen viestintään on koitunut koko järjestelmän ongelmaksi, sillä haitallisen roskapostin osuus on koko sähköpostiviestinnästä noussut arvion mukaan 80 prosenttiin (esim. D-Fence Oy:n tilastot; Viestintävirasto CERT-FI Ohje 3/2003). Internetin laajuus ja hallitsemattomuus on tuottanut joukon säännöksiä, jotka koskevat tietoyhteiskunnan pelisääntöjä ja sähköistä viestintää (Aarnio 2004; Harjuhahto-Madetoja 2004). Useat kirjalliset esitykset (esim. Flynn \& Kahn 2003), Suomen sähköpostilainsäädännön ensimmäiset versiot (esim. Hallituksen esitys... 2003), laajat valtakunnalliset hankkeet (esim. Tietoyhteiskuntaohjelma ja kansalliset tietoturvatalkoot) sekä lukuisat kansalliset ja kansainväliset digitaalisen kulttuurin konferenssit ja seminaarit (esim. Tietoyhteiskunnan pelisäännöt ja yksityisyys -seminaari) ovatkin yrityksiä ymmärtää sähköpostiviestinnän ja muun digitaalisen kulttuurin luonnetta ongelmineen.

Tähänastinen sähköpostiviestinnän tutkimus on ollut näkökulmaltaan lähinnä teknis- tai viestintätieteellistä ja kohteena ovat olleet erilaiset työssä tapahtuvaan sähköpostin käyttöön liittyvät teemat (esim. Whittaker et al. 2005; Liu 2002). (1) Viestijä ja viestin sisällöt nousevat kuitenkin korostuneina esiin, kun tutkitaan viestien lähettämisen ja vastaanottamisen prosesseja sekä sisältöjä. Sähköpostiviestintää ei ole mahdollista ymmärtää yksinomaan teknisistä lähtökohdista käsin. Sähköpostiviestinnän kulttuurisiin ulottuvuuksiin liittyvän ymmärryksen lisääminen onkin ajankohtaista ja tärkeää, sillä tällaista tutkimusta on tehty vähän. Jari Aron (2003) (2) empiirinen tutkimus sähköpostihuumorista on ollut positiivinen 


\section{Kari Salo, Kaj Zimmerbauer, Timo Suutari}

avaus kotimaiselle sähköpostin kulttuuriselle tutkimukselle ja samalla jatkoa Ulla Lipposen (1989), Seppo Knuuttilan (1992), Aarne Kinnusen (1994) ja Marja Ylösen (1995) huumoritutkimuksille.

Tämän artikkelin tavoitteena on täydentää sähköpostiin liittyvää kulttuurista tutkimusta ja tuoda siihen myös uutta näkökulmaa. Tarkastelunäkökulmia on kaksi: yhtäältä artikkelissa tarkastellaan sosioemotionaaliseen säbköpostiviestintään liittyviä erilaisia näkökulmia, ja toisaalta, viestien sisältöjen osalta, artikkelissa ollaan kiinnostuneita eteläpohjalaisunden ilmentymistä. Kun ensimmäinen näkökulma keskittyy sosioemotionaalisen sähköpostiviestinnän funktioihin, jälkimmäinen liittyy kielen käytön todellisuutta rakentavaan luonteeseen, joka tässä tapauksessa tiivistyy alueen eli Etelä-Pohjanmaan kielelliseen tuottamiseen ja uusintamiseen. Tutkimusaineiston avulla tavoitteena onkin tarkastella eteläpohjalaisuuden tuottamista sähköisen viestinnän henkilökohtaisissa ja epävirallisissa yhteyksissä.

Sosioemotionaalinen sähköpostiviestintä määrittyy tässä artikkelissa ensisijaisesti eteläpohjalaissisältöiseksi vertaisviestinnäksi, joka ei perustu työhön eikä professioihin vaan enemmänkin yhteisöllisyyden ilmentämiseen. Alueellinen identiteetti rajataan puolestaan koskemaan ihmisten alueellista identiteettiä eli niin sanottua aluetietoisuutta ja aluesamastumista (Paasi 1986, 35-37).

Artikkelin lähtökohtana on hämmästys sähköpostitse leviävien viestien runsaudesta ja sähköpostiviestinnän eri ulottuvuuksista. (Etelä)pohjalaisuuteen liittyvien sähköpostiviestien rajaamiseen tutkimuskohteeksi on vaikuttanut kirjoittajien eteläpohjalainen tausta sekä se, että Etelä-Pohjanmaan maakuntaidentiteetin on todettu olevan hyvin vahva (Paasi 1986, 235-239; Zimmerbauer 2002). Artikkelin teoreettinen viitekehys rakentuu pääosin sosioemotionaalisen sähköpostiviestinnän tutkimukseen ja sähköpostiviestintään liittyvään keskusteluun, minkä lisäksi aineistoa peilataan alueellisen identiteetin teoretisointeihin. Miten sähköpostiviestintä tuottaa ja uusintaa eteläpohjalaista identiteettiä? Tutkimusta motivoi myös kiinnostus nykyperinteen luonteesta digitaalisessa ympäristössä. Miten identiteetin tunnusmerkit ovat mukautuneet sosioemotionaalisessa sähköpostiviestinnässä sisältöjen, mediaelementtien ja sähköpostihuumorin osiksi tuottaessaan kuvaa (etelä)pohjalaisuudesta?

Tuomme esiin uudenlaisia maakuntaidentiteetin tuottamismekanismeja ja erityisesti sosioemotionaalisen sähköpostiviestinnän merkitystä alueellisen identiteetin rakentajana. Tällöin olettamuksena on, että maakuntaidentiteetti syntyy ja sitä ylläpidetään paitsi perinteisten maakunnan tai muun alueen institutionalisoitumiseen liittyvien mekanismien kautta (ks. esim. Paasi 1986; Häkli 1994) myös tietoverkkojen ja sähköisen viestinnän välityksellä. Artikkelissa pyritäänkin linkittämään sähköpostiviestintä alueellisen identiteetin muodostumista käsittelevän teorian osaksi. 


\section{SÄHKÖPOSTI VIESTINNÄN VÄLINEENÄ}

Tieto on noussut neljänneksi tuotannontekijäksi työn, pääoman ja raaka-aineen rinnalle. Koska tietoyhteiskunta keskittyy tiedon, ideoiden ja osaamisen kautta aineettomiin hyödykkeisiin, ruumiillinen työ korvautuu yhä useammin henkisellä työllä. Samalla verkostoitumisen eli yhteistoiminnan, kanssakäymisen ja kommunikoinnin merkitys lisääntyy. Jussi Vähämäen (2004, 55) mukaan uudenlaisessa informaatiotaloudessa ja verkostoituneessa työssä tarvitaan erityisesti kommunikaatiokykyjä, joilla organisoidaan ja yhdistellään erilaisia sisältöjä. Kommunikaatiokyvyt ovat keskeisessä roolissa tietotyössä, jossa työntekijän henkilökohtaiset ominaisuudet sekä kyky käyttää tietoa ja erilaisia viestintävälineitä korostuvat (esim. Reich 1995; Pyöriä 2001).

Sähköpostiviestintä on yksi tärkeimmistä sähköisen viestinnän muodoista, jonka sisältö voidaan määritellä kahtalaiseksi. Tehtäväorientoitunut sähköpostin käyttö kohdistuu työtehtäviin, kun taas sosioemotionaalisessa viestinnässä otetaan etäisyyttä työhön ja pidetään yhteyttä ystäviin (Sproull \& Kiesler 1986, 1492-1512; Steinfield 1985, 239-243; Steinfield 1986, passim. Vrt. Aro 2003). (3) Charles W. Steinfieldin (1985, 239-243; ks. myös Heinonen 2001) mukaan tavallisin sähköpostin käyttömuoto on tehtäväorientoitunut informaation vaihto. Organisaatioiden sähköpostipalveluja ja työpaikan sähköpostiosoitetta käytetään myös muuhun kuin työhön liittyvään viestintään. Suomalaisten sähköpostin käyttöpaikoista ei ole saatavilla tilastotietoa, mutta internetin käyttöpaikoista tyypillisimmiksi on todettu koti, työpaikka, ystävät tai sukulaiset, oppilaitos, kirjasto ja muut yhteiskäyttöpisteet (Nurmela \& Sirkiä 2004). Työpaikan voi kuitenkin olettaa korostuvan sekä tehtäväorientoituneen että sosioemotionaalisen sähköpostin käyttöympäristönä. (4)

Toisaalta jyrkkä eronteko työhön liittyvän ja työstä etäisyyttä ottavan sosiaalisen sähköpostin käytön välillä ei ole tarpeen, sillä sosiaalisten suhteiden ja epävirallisten verkostojen ylläpitäminen on työelämän kannalta tärkeää (vrt. Vähämäki 2004). Sosioemotionaalinen sähköpostiviestintä tuo esiin esimerkiksi sen, miten työntekijät reagoivat työn vaatimuksiin sekä miten he hyödyntävät sähköpostin viestinnällisiä ja yhteisöllisiä mahdollisuuksia. Sosiaalisen pääoman kerääminen ja hoitaminen sekä verkostoituminen onnistuvat sähköisen viestinnän välinein. Sähköposti ja muut uudet viestinnän muodot myös murtavat joukkoviestintään liittyvää massa-ajattelua ja ylhäältä alas suuntautuvaa tiedon jakamisen tapaa. Syntyy uutta yhteisöllisyyttä ja kulttuuria (5), sillä sähköinen viestintä tuottaa sekä ulkopuolisuutta ja objektina olemista että osallisuutta ja subjektina toimimista. Yksilön kannalta on erittäin tärkeää, millaisiin verkostoihin hän pääsee mukaan (ks. Savolainen 1995).

Sähköiseen viestintään liittyvän paikan ja ajan problematisointi luovat mielenkiintoisen jännitteen alueellisen identiteetin muotoutumiseen. Kulttuurien tutkimuksen näkökulmasta tämä voidaan realisoida esimerkiksi folklore-poploreelore -jatkumolle. Kun folkloren kohdalla paikallisuus on vielä voimakasta, poploren kohdalla kyseessä ovat usein joukkotiedotuksen välityksellä levinneet, vähemmän paikallisesti sitoutuneet ilmiöt. Eloren kohdalla puolestaan on kyse tietoverkoissa 
tapahtuvasta digitaalisesta viestinnästä ja virtuaalisesta kulttuurista, jolloin paikan, etäisyyden ja ajan merkitykset muuttuvat eivätkä yhteisöllisyyden ja identiteetin tuottamisen prosessit ole enää niin paikkasidonnaisia.

\section{AlueELlisen IDENTITEETIN TUOTTAMINEN SOSIOEMOTIONAALISESSA SÄHKÖPOSTIVIESTINNÄSSÄ}

Identiteetti on monitahoinen käsite, jonka märittelytavat vaihtelevat esimerkiksi tieteenalasta riippuen. Usein identiteetistä on kuitenkin tapana puhua ryhmien, yhteisöjen ja sosiaalisten järjestelmien yhteydessä, jolloin kyse on kollektiivisesta identiteetistä. Kollektiivinen identiteetti on ennen kaikkea kulttuurinen ilmiö, johon liittyy yhteisesti tunnistettuja merkityksiä, jotka ovat syntyneet historian kuluessa itsemme ja toisten tunnistamiseksi. Nämä merkitykset ovat luonteeltaan kulttuurisia, ja ne ovat kiteytyneet symbolisiin koodeihin. Symboliset koodit ilmenevät toistuvina ilmauksina, myyttisinä kertomuksina ja symboleina sekä itsestään selvinä merkityksinä. Kollektiiviset identiteetit koostuvat suurelta osin sellaisista symbolisista koodeista, joita voidaan kutsua myyteiksi. Myyteillä tarkoitetaan vakiintuneita kertomuksia, ilmaisutapoja sekä merkkejä ja tapoja. Esimerkiksi suomalaisuuteen liittyviä kansallisen identiteetin myyttejä ovat sisu, sauna ja Sibelius. (Kaunismaa 1997a, 40-42; 1997b, 220.)

Identiteettikeskustelussa painopiste on siirtynyt yhä enemmän ajan, paikan ja tilan kontekstiin, jolloin alueellisen identiteetin ja aluetietoisuuden käsitteet ovat nousseet keskeisiksi teemoiksi (ks. esim. Hänninen 1998, 9-10). Alueellisessa identiteetissä on kyse nimenomaan tulkinnoista ja käsityksistä siitä, mitä "me" olemme. Alueellisen identiteetin käsitteeseen liittyy kaksi näkökulmaa: alueen itsensä identiteetti sekä ihmisten alueellinen identiteetti. Alueen identiteetti koostuu sellaisista alueen ominaisuuksista, joiden perusteella alue erottuu muista. Näitä ominaisuuksia ovat alueellisen luokittelun perustekijät, kuten luonnonolot, historia, sosiaalinen rakenne, kulttuuri, kieli ja murteet. Näiden pohjalle perustuu mielikuvat ja odotukset, joita alueeseen liitetään. Ihmisten alueellinen identiteetti voidaan ymmärtää aluetietoisuutena, mikä tarkoittaa ihmisen samastumista jollekin tietylle alueelle, esimerkiksi maakuntatasolla kuulumista Etelä-Pohjanmaalle kaikkien muiden maakuntien sijaan. (Alueellisen identiteetin käsitteestä ks. Paasi 1986.)

Maakuntatasolla alueelliset identiteetit ovat muodostuneet monin eri tavoin. Pekka Kaunismaa (1997a, 44; ks. myös Talvitie 2000) toteaa, että esimerkiksi karjalaisuuden ja hämäläisyyden alkupistettä ei voida määritellä saatavilla olevan informaation valossa, vaikkakin ensimmäiset maininnat niin sanotuista historiallisista maakunnista ovat peräisin jo 1300-luvulta. Toisaalta esimerkiksi keskisuomalainen identiteetti on vakiinnuttanut asemaansa vasta läänin perustamisen jälkeen vuonna 1960. Lisäksi on muistettava, että maakuntaidentiteetit, muiden alueellisten identiteettien tavoin, ovat jatkuvassa muutoksessa. Olennaista alueellisessa 
identiteetissä onkin se, että se on yhteisötason käsite ja viittaa perusteisiin, joilla alue erottuu laajemmasta yhteisöstä omaksi kokonaisuudekseen (Paasi 1986, 35-36; Kivistö 1997, 81-82).

Alueellinen identiteetti rakentuu alueen kielellisen tuottamisen kautta, eli sitä voidaan pitää kielellisenä konstruktiona. Kielellinen tuottaminen on ymmärrettävä laajasti, eli siihen kuuluu paikan symboloiminen teksteiksi, kuviksi, ääniksi ja erilaisiksi muiksi merkeiksi, joita ovat esimerkiksi maakuntavaakunat, -kukat tai -eläimet. Paikan tai alueen kielellistä tuottamista ei kuitenkaan tule ymmärtää neutraaliksi "todellisuuden" kuvaukseksi vaan presentaatioksi ja representaatioksi, jotka perustuvat tulkintoihin, kokemuksiin ja erilaisiin motiiveihin (esim. Barnes \& Duncan 1992, 2). Kyse on alueen käsittämisestä eräänlaisena diskursiivisena projektina. Identiteetti liittyy alueen tunnistamiseen ja omaksi kokemiseen. Identiteetti onkin syytä ymmärtää alueen (luonnollisina) ominaisuuksina, mutta ennen kaikkea aluetietoisuutena ja aluesamaistumisena.

Perustellusti voidaan kysyä, miten tietoverkkojen kehittyminen on vaikuttanut alueellisen identiteetin rakentumisen prosesseihin. Voidaan olettaa, että "vanhat" maakuntaidentiteetin rakennusainekset ovat saaneet tietoverkoista ja verkkoviestinnästä rinnalleen uudenlaisia välineitä. Daniel Miller ja Don Slater havaitsivat trinidadilaisten internetin käyttöön liittyvässä etnografisessa tutkimuksessaan, että globaali tietoverkko on toiminut trinidadilaisille merkittävänä alueellisen identiteetin vahvistumisen alustana. Samalla tutkitut kokivat sähköpostiviestinnän suhteellisen konkreettiseksi, arkipäiväiseksi ja hyväksytyksi asiaksi, koska se mahdollisti jatkuvan, pysyvän ja itsestään selvyytenä pidettävän päivittäisen kontaktin perheenjäsenten ja sukulaisten kesken. (Miller \& Slater 2000, 7, 11). Alueellisen identiteetin rakentumisen kannalta viestien lähettämisellä ja vastaanottamisella onkin sosiaalinen ja verkostoja luova funktio, kun taas erilaiset alueeseen liittyvät viestit sisältävät symboleita, jotka vahvistavat alueeseen samastumista tuottaen ja uusintaen alueeseen liittyviä mielikuvia. Identiteetti rakentuu sekä itse viestintätoiminnan että viestien sisältöjen kautta.

\section{TutKImUSAINEISTON KUVAUS Ja ANALYYSI}

Tämän artikkelin aineiston muodostaa 28 (etelä)pohjalaisuuteen liittyvää autenttista sähköpostiviestiä ja niiden sisältämää liitetiedostoa tai linkin kohteena olevaa internetsivua. Se on osa 520 sähköpostiviestistä koostuvaa kokonaisuutta, joka on kerätty vuosina 2001-2004. Aineistossa on sekä yksityishenkilöiden tutkija Kari Salolle henkilökohtaisina viesteinä lähettämiä sähköposteja että erikseen pyydettyjä viestejä. Yksityishenkilöille kerrottiin, että tutkija on kiinnostunut epävirallisesta (sosioemotionaalisesta) sähköpostiviestinnästä, kaikki aiheet ovat tervetulleita, viestin lähettäjän tunnistetiedot pidetään salassa ja tutkija tekee aiheesta sosiologiasta väitöskirjaa. Lisäksi aineistoa toimittavia henkilöitä pyydettiin käyttämään sähkö- 


\section{Kari Salo, Kaj Zimmerbauer, Timo SuUtari}

postiohjelman "välitä" -toimintoa ja pidättäytymään minkäänlaisesta viestien muokkaamisesta ennen lähettämistä.

Aineisto paikantuu Seinäjoella toimiviin korkeakouluyksiköihin, yrityksiin ja koulujen toimijoihin sekä tutkijan omiin ystäväverkostoihin. Aineistonkeruupyyntö levisi myös tämän verkoston ulkopuolelle. Kokonaisuudessaan tutkija Salo rajasi aineiston yhteensä 520 viestiin, vaikka kyseisiä sähköpostiviestejä oli saatavilla enemmänkin. Syynä rajaukselle oli aineiston kyllääntyminen sekä aineiston hallinnan ja koodaamisen vaatima suuri työmäärä. Tässä artikkelista käytetyn aineiston rajaus tehtiin vuoden 2004 lopussa. Aineisto on kuvailtu lyhyesti Taulukossa 1.

\section{Taulukko 1. Tutkimusaineiston kuvaus}

Juokseva numerointi, viestin aihe tai tiedoston nimi/ tiedoston otsikeko sekä sisällön lybyt kuvaus.

1. Pohojalaaset rules!

Vitsin sisältävä tekstuaalinen sähköpostiviesti, jossa pohjalainen on nostettu eri valtioiden kansalaisten rinnalle ja omalla tavallaan ohi.

2.-5. Almanakka/Pohojalaanen kalenteri/Pohojalaanen alamanakka 2003/ kalenteri pohojanmaalta.

Vuosikalenterin sisältävä sähköpostiviestin liitetiedosto, jossa vanhahtavat mustavalkoiset valokuvat on paikallistettu Etelä-Pohjanmaalle murretta hyödyntäen.

6.-8. Pohojalaastesti/Mistoot kotoosin?/POHOJALAANE?

Tekstuaalinen sähköpostiviesti, joka jäljittelee rakenteeltaan erilaisia tunnistustestejä.

9. Pohjalaanen kevättesti.

Sähköpostiviestin html-liitetiedosto, joka on edellisen kaltainen tunnistustesti.

10.-11. POHOJALAASIA LIIKENNESÄÄNTÖJÄ Autoolijoolle/Pohojalaaset liikennesäännöt Autoolijoolle:, Pyärälijöölle: ja Jalankulukijoolle

Yhteensä 16 kappaletta murteella esitettyjä mustan humoristista sääntöä.

Tekstuaalinen sähköpostiviesti ja internet-linkin sisältävä sähköpostiviesti.

12. Pohojalaane Horoskooppi

Internet-linkin sisältävä sähköpostiviesti, jossa murteella humoristisesti esitellään horoskooppimerkit.

13. Käsitteitä

Internet-linkin sisältävä sähköpostiviesti internet-sivulle, jossa määritellään yhdeksän eteläpohjalaista käsitettä.

14. Pohojalaaset taivutukset. Moon oikias, Soot vääräs, Son kans vääräs

Internet-linkin sisältävä sähköpostiviesti, jossa sijamuodot on murteella

humoristisesti esiteltynä. 


\section{ETELÄPOHJALAISUUS SOSIOEMOTIONAALISESSA SÄHKÖPOSTIVIESTINNÄSSÄ}

\section{5.-16. POHOJALAANEN MAISEMA - Kuinka saara siitä raakasti irti/}

Tottajukolauta

Internet-linkin sisältävä tekstuaalinen sähköpostiviesti, joka sisältää murteella opastetun (hyper)tekstiseikkailun pääosin Etelä-Pohjanmaan maakunnan alueella.

\section{Korrektia käytöstä pohjalaisittain}

Internet-linkin sisältävä sähköpostiviesti, jonka murreilmaisua käyttävä sisältö käsittelee stereotyyppisiä käsityksiä eteläpohjalaisuudesta erityisesti liittyen maakunnan asukkaiden suvaitsevaisuuteen.

18.-19. KUR MOO TUS/kurssi kurmootuksesta

Tekstuaalisia sähköpostiviestejä, joissa murreilmaisua käyttäen kerrotaan eteläpohjalaisesta väkivaltakulttuurista.

20. Pohojalaasia sanoja ja sanontoja muille suomalaisille

Internet-linkin sisältävä sähköpostiviesti, jonka sisältönä on murresanojen ja sanontojen selittäminen.

\section{Sami Rastilan edesottamuksia}

Internet-linkin sisältävä viesti, jossa Sami Rastila -niminen henkilö suunnistaa maakunnan alueella.

22.-23. Jouluressi-testi pohjalaisittain/Pohojalaanen jouluressi-testi

Tekstuaalisia sähköpostiviestejä, jotka murretta käyttäen kehottavat testaamaan joulustressin tason.

24. Ellit estradilla

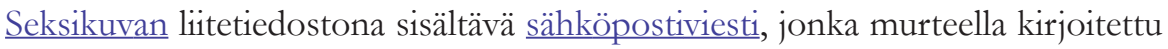
otsikointi viittaa alueen kansanmusiikkiperinteeseen.

\section{Pohjanmaa-kappale}

Joulutervehdyksenä lähetetty viesti, joka sisältää liitetiedostona musiikkitiedoston ja linkin kyseisen kappaleen esittävän yhtyeen internetsivuille.

26.-27. Pohojalaanen terveyskortti/Pohojalaanen terveyskortti

Molemmat viestit sisältävät kolmesivuisen liitetiedoston, joka sisältää laajahkon terveyden ja hyvinvoinnin osatekijöiden kartoituksen murteella ja huumorilla höystettynä.

28. Pohojalaanen siipanhakuilmootus

Tekstuaalinen sähköpostiviesti, joka murretta käyttäen kehottaa täyttämään kyselylomakkeen ja lähettämään aviopuolisoehdokkaille. 


\section{Kari Salo, Kaj Zimmerbauer, Timo Suutari}

Aineistoa on tarkasteltu ja luokiteltu artikkelissa kahdella eri tasolla. Ensimmäinen taso on luonteeltaan tekninen, jolloin tarkastelun kohteena on se, mitä eri multimediaelementtejä viesteissä mahdollisesti on byödynnetty. Tekniseen analyysiin voidaan lukea kuuluvaksi myös "kielen pintataso", jolloin ollaan kiinnostuneita siitä, rakentuuko koko viesti murteen varaan tai liittyykö viestin sisältö eteläpohjalaisuuden elementteihin. Toinen analyysin taso on aineistolähtöistä sisältöanalyysiä, jonka yhteydessä huomiodaan muun muassa se, miten (etelä)pohjanmaa määrittyy ja käsitteellistyy viesteissä.

Näiden lisäksi viestejä on tarkasteltu sosioemotionaalisen sähköpostiviestinnän näkökulmasta, jolloin tarkastelun kohteena ovat viestinnässä ja itse viesteissä käytetyt keinot, jotka ilmentävät niiden epävirallista ja työviestinnästä erottuvaa funktiota. Aineisto ei anna mahdollisuutta tutkia lähettämistä ja vastaanottamista, joten lähettäjien motiiveja ja viestien vaikuttavuutta ei tässä artikkelissa juurikaan tarkastella. Sen sijaan analyysin kohteena on sosioemotionaalisen sähköpostiviestinnän luonne eteläpohjalaista identiteettiä luovana ja vahvistavana prosessina. (6)

\section{EI NIIN TEKNISTÄ, MUTTA "LEVIÄÄ"}

Tutkimusaineistona olleiden sähköpostiviestien tekniset toimitustavat jakaantuivat melko tasaisesti. Yhdessätoista tutkitusta viestistä varsinainen sisältö oli tekstin muodossa sille tarkoitetussa viestikentässä, yhdeksässä viestissä sisältö oli linkin muodossa ja kahdeksassa sähköpostiviestissä liitetiedostona. Tutkitut sähköpostiviestit olivat suurimmaksi osaksi tekstimuotoisia tarinoita, joskin aineistosta löytyi muitakin mediaelementtejä (valokuvat, musiikkitiedostot, hypertekstit ja linkit). Multimediaelementtejä eli muuta kuin tekstiä hyödyntäviä viestejä oli aineistossa yhteensä 17 kappaletta (Taulukko 1). Online -interaktiota ja hypertekstejä oli hyödynnetty pohjalaista maisemaa läpäisevissä tarinavarianteissa, jotka veivät tekstissä mainittujen Etelä-Pohjanmaan kuntien ja yhteisöjen internetsivuille. Toisessa samansisältöisessä viestissä nämä hyperlinkit eivät enää toimineet, joten pääpaino rajautui ainoastaan tekstimuotoiseen tarinaan. Joissakin viesteissä oli käytetty animaatioita, mutta videoita ja tietokantoja hyödyntäviä viestejä ei aineistossa ollut lainkaan. Aineistossa neljänä eri versiona esiintyvässä almanakassa valokuvat olivat osa tarinaa ja tuotetta (Taulukko 1, kohta 2-5), kun taas sähköpostin liitteenä lähetetty sisällöltään seksuaalinen valokuva (Taulukko 1, kohta 23) oli paikallistettu Etelä-Pohjanmaalle kuvan päälle editoidulla tekstillä: "! Ellit estradilla! Suosittu Perä-Seinäjokelainen nahka-fagotti -kvartetti soittaa kauneimpia kansansäveliämme posket lommolla...” 


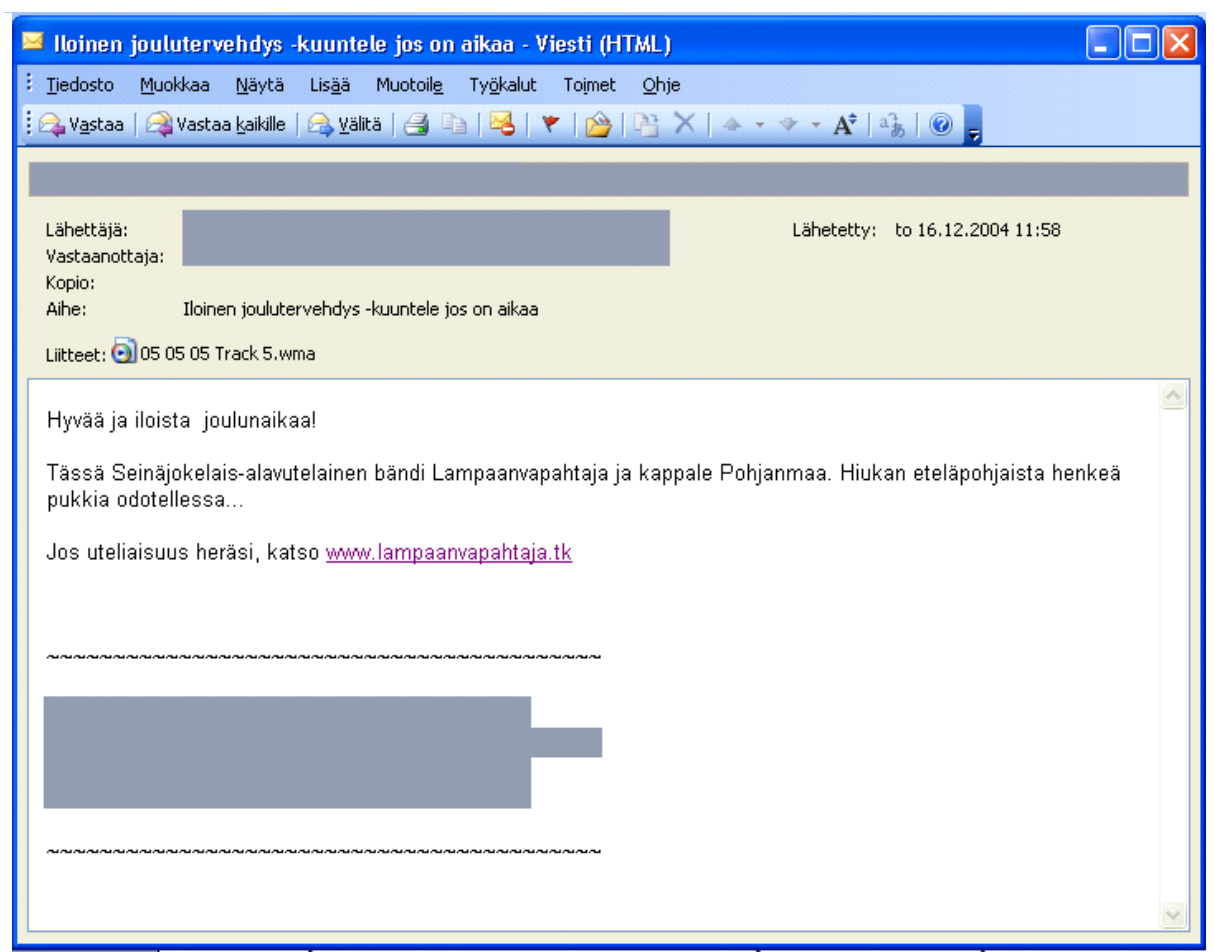

Kuvio 1. Esimerkki sosioemotionaalisesta sähköpostiviestinnästä

Pohjanmaa -nimisen punk-rock -tyylisen kappaleen sisältävän Windows Media -äänitiedoston (Taulukko 1, kohta 25) lähetti puolestaan eräs työntekijä joulutervehdyksenä kaikille muille organisaationsa työntekijöille eli yhteensä noin 600 henkilölle (Kuvio 1). Viesti ilmentää useita sosioemotionaalisen sähköpostiviestin ominaisuuksia. "Lähettäjä" ja "vastaanottaja" -kenttiä ei välttämättä tämänkaltaisessa viestinnässä käsitellä, vaan oletusasetuksena toimiva "kaikki näkevät kaiken" -periaate hallitsee viestinnässä. Aihekentässä on tarkoitus kertoa vastaanottajalle viestin aihe, mutta sitä voidaan käyttää muidenkin merkitysten tuottamiseen kuten esimerkissämme, jossa viestin aloitus tapahtuu adjektiivilla "iloinen" ja sitä seuraavat sisällöllinen substantiivi "joulutervehdys" sekä lause: "kuuntele jos on aikaa." Näiden seikkojen esiintuominen jo aihekentässä kertoo lähettäjän olevan tietoinen tekemisistään, sillä niiden tavoitteena on mitä ilmeisimmin sekä teknisesti että sisällöllisesti ehkäistä ärtymystä, jota tällaiset viestit joissakin vastaanottajissa voivat aiheuttaa. "Kuuntele jos on aikaa" -ajatus ilmaisee sosioemotionaalisen sähköpostiviestinnän erään perusmotiivin: se toimii vastapainona työlle ja työviesteille samalla, kun se käyttää hyväkseen useita työnantajan kustantamia resursseja. Toisaalta kuitenkin esimerkkiviestissä ilmenevät myös virallisen työyhteisöviestinnän käytännöt, sillä lähettäjä on allekirjoittanut viestin omalla nimellään ja liittänyt viestin loppuun yhteystietonsa. Muissakaan aineiston sisältämissä viesteissä lähettäjän anonyymiys ei ollut tarpeen, vaan lähettäjä toi itsensä esiin avoimesti. Esimerkki- 
viestissä yksilön halu ja oikeus antaa eteläpohjalainen ja humoristinen "joululahja" kaikille työyhteisön jäsenille ilmentää eteläpohjalaista henkeä ja identiteettiä. Samassa hengessä lähettäjä haluaa välittää laajalle vastaanottajien joukolle linkin muodossa tietoa kyseisestä yhtyeestä. Sähköpostiviestin liite, jonka nimeä ei ole huoliteltu, oli kooltaan 1,32 megatavua. Tässä hyvin rajallisessa aineistossa se oli suurin yksittäinen viesti, mutta koko sähköpostiviestinnän mittakaavassa sitä ei voida pitää tiedostokooltaan kovinkaan suurena.

Osin teknisestä rajoittuneisuudestakin johtuen viestien tarinamuotoisuus ja murretekstuaalinen luonne korostui. Koko aineisto oli kirjoitettu Etelä-Pohjanmaan murteella, joskin murteen määrä ja käyttötapa vaihtelivat jossain määrin. Johtuen aineiston keruutavasta tutkimusaineistossa lähettäjänä oli tavallisesti eteläpohjalainen henkilö samoin kuin vastaanottajanakin. Vaikka tässä artikkelissa ei tarkastella sitä, keitä lähettäjät ja vastaanottajat tyypillisesti ovat, viestijöiden voidaan todeta olevan maakunnassa tai sen ulkopuolella asuvia eteläpohjalaisia.

\section{"MOOMMA OIKIAS, TOOTTA VÄÄRÄS, NON AIVAM METTÄS"}

Etelä-Pohjanmaan maakuntaan kuuluu yhteensä 26 kuntaa. Maakunnan keskuskaupunki on Seinäjoki. Aineistossa mainittiin suurin osa maakunnan kunnista erikseen, ainoastaan viittä kuntaa, Evijärveä, Isojokea, Karijokea, Lehtimäkeä ja Soinia, ei mainittu. Lisäksi naapurimaakuntien kunnista tulivat mainituiksi Laihia, Vaasa, Vöyri, Vähäkyrö ja Perho - kuitenkin siten, ettei näiden alueiden sekoittumisesta Etelä-Pohjanmaahan ollut viitteitä. Toisaalta Etelä-Pohjanmaa vaikutti paikoitellen kattavan myös nykyisen Pohjanmaan maakunnan eli kutakuinkin koko historiallisen Etelä-Pohjanmaan alueen. Markku Kulmala (2003, 151) toteaakin, että "eteläpohjalaiseksi rajaaminen on aina tulkinnanvaraista ja subjektiivista". Kokonaisuudessaan alueellisuus oli viesteissä ja tarinoissa melko satunnaista ja hajanaista, mutta aineiston teksteistä Almanakka variantteineen (Taulukko1, kohdat 2-5), Sami Rastilan edesottamuksia esittelevä internetsivusto (Taulukko 1, kohta 21) sekä "Pohojalaanen maisema, kuinka saara siitä raakasti irti" (Taulukko 1, kohta 15) sisälsivät tietoisen rakenteen Etelä-Pohjanmaan alueellisen määrittymisen pohjalta. Yleisemmällä tasolla voidaan kuitenkin ajatella, että tietoverkkojen myötä - ja etenkin sosioemotionaalisessa sähköpostiviestinnässä - makunta käsitteellistyy paremminkin tiettyinä verrattain paikattomina elementteinä ja merkityssisältöjen joukkona kuin tarkasti rajattuna territoriona.

Kaj Zimmerbauerin Etelä-Pohjanmaan imagoa käsittelevässä tutkimuksessa Etelä-Pohjanmaan imago. Maakunnallisten mielikuvien jäljillä (2002) kysyttiin 788:lta maakunnan ulkopuolella asuvalta henkilöltä, millaisia asioita heille tulee EteläPohjanmaasta mieleen. Vastausten perusteella Etelä-Pohjanmaan symbolit ja myytit kiteytyvät neljään kokonaisuuteen, joita ovat tasainen maisema eli lakeus, yrittäjähenkisyys, puukko ja häjyt sekä Eteläpohjalainen kansanluonne ja ihmiset. (Zimmerbauer 2002, 40-41.) Eteläpohjalaiseen kansanluonteeseen yhdistyy tutki- 


\section{ETELÄPOHJALAISUUS SOSIOEMOTIONAALISESSA SÄHKÖPOSTIVIESTINNÄSSÄ}

muksen mukaan yritteliäisyys, suorapuheisuus, rehellisyys ja ahkeruus mutta myös itsekkyys ja itsellisyys, jopa itsepäisyys. Lisäksi eteläpohjalaisia luonnehdittiin uskonnollisiksi, isänmaallisiksi ja jäyhiksi mutta sanansa pitäviksi sekä itsetietoisiksi. Aineiston perusteella voidaan todeta, että viesteissä korostuvat yleisimmät maakuntaan liittyvät mielikuvat sekä erityisesti kaikkein tunnetuimpina pidetyt pohjalaiset luonteenpiirteet, joiden tehoa vielä korostaa murteellinen kirjoitusasu. Erityisesti "Pohojalaane kevättesti" (Taulukko 1, kohta 9) keskittyy eteläpohjanmaalaisten luonteenpiïrteiden kuvailuun: 'Kevät lähenöö, joten tehekääpä tämä testi niin tiärättä mitä o olla pohojalaane. Samalla huamaatta oottako itte yhytää pohojalaas-verisiä." Testin mukaan eteläpohjalaisen stereotyyppinen kokokuva on luonnonläheinen, maalainen, omistamisenhaluinen, vähemmän kouluja käynyt, oikeistolainen, isänmaallinen ja hulivili heteromies.

Tunnetuiksi eteläpohjalaisten luonteenpiirteiksi nousevat sisukkuuden ja jämäkkyyden ohella uhoaminen, toimeliaisuus ja yritteliäisyys. Yrittäjyyden korostuneisuuden sekä muiden viittausten myötä eteläpohjalainen identifioituisikin ideaalitapauksessa mieluummin työnantajaksi kuin työntekijäksi: "Sun peltua on niin pitkältä ja leviältä notta kestää päivän ku renki ajaa maasturilla saraan päästä päähän". Tällaisen "suuruudenhulluuden" nähdään olevan yksi pohjalaisten tuntomerkeistä, jolle esimerkiksi Vesa Keskinen on antanut kasvot: "Suomen suurin kyläkauppa Töysän Tuuris vetää väkiä bussilasteittain maakunta- ja maan rajojen takaa. Pohojalaasia tituleerataha joskus suuruuren hulluuksi, mutta kauppias Vesa Keskinen on jotaki viälä enemmän.” (Taulukko 1, kohta 16.) Toisaalta Keskisen voidaan nähdä hyödyntävän taitavasti juuri näitä eteläpohjalaisuuteen liitettäviä mielikuvia yrityksensä brandissa, jossa eteläpohjalainen suuruudenhulluus "miljoonapilkkeineen" toimii houkuttimena. Toisena esimerkkinä eteläpohjalaisesta yrittäjyydestä ja suuruudenhulluudesta voi mainita Jorma Lillbackan Mika Salo Circuit karting-radan, Euroopan suurimman karting-hallin ja Power Land -huvipuiston Alahärmässä.

(Etelä)pohjalaisuudesta esitetyt tyypillisimmät luonteenpiirteet ovat sähköpostiviesteissä esillä karikatyyrisessä ja stereotyyppisessä muodossa huumorin ollessa tyyliltään karnevalistista eli sääntöjä tietoisesti rikkovaa (ks. myös Aro 2003; Leppälahti 2002). Osassa viestejä murretta on käytetty hyvin karrikoivalla tavalla, ja paikoin mustanpuhuva huumori leimaa viestien sisältöä tehden pohjalaisista ihmisistä kovia ja häpeilemättömiä. Viesteissä korostui, että pohjalainen seisoo sanojensa takana ja taistelee haluamansa puolesta: "sinoot poikkeuksetta oikias ja muut vääräs" (Taulukko 1, kohta 7).

Itsellisyys ja eteenpäin meneminen tuodaan esiin olennaisina piirteinä, ja näiden vastailmiöinä esiintyvät viesteissä jonottaminen ja pakoon lähteminen häpeää aiheuttavina toimintoina: "Ei suuret sanat suuta halkaise. Älä siis turhaan hukkaa aikaa sovintoyrityksiin. Pakoon lähteminen ei ole kiellettyä, mutta helvetinmoinen häpeä. Älä siis pakene. Mitä enemmän nostat penkistä, sitä röyhkeämmin voit etuilla jonoissa.” (Taulukko 1, kohta 18-19.) Itsellisyys on viesteissä omanarvontuntoa, 


\section{Kari Salo, Kaj Zimmerbauer, Timo Suutari}

omaehtoisuutta, omista oikeuksista huolehtimista, narsismia ja joskus kiusan tekemistä ja uhoakin - kaikkea mitä autonomia ja identiteetti kulloinkin edellyttävät (esim. Taulukko 1, kohta 10-11).

Sosioemotionaaliselle sähköpostiviestinnälle tyypilliset aihealueet ja viestintätyylit hallitsevatkin eteläpohjalaisuutta käsitteleviä sähköpostiviestejä. Sähköpostiviestien sisällöt jakaantuivat aineistossa seuraavasti:

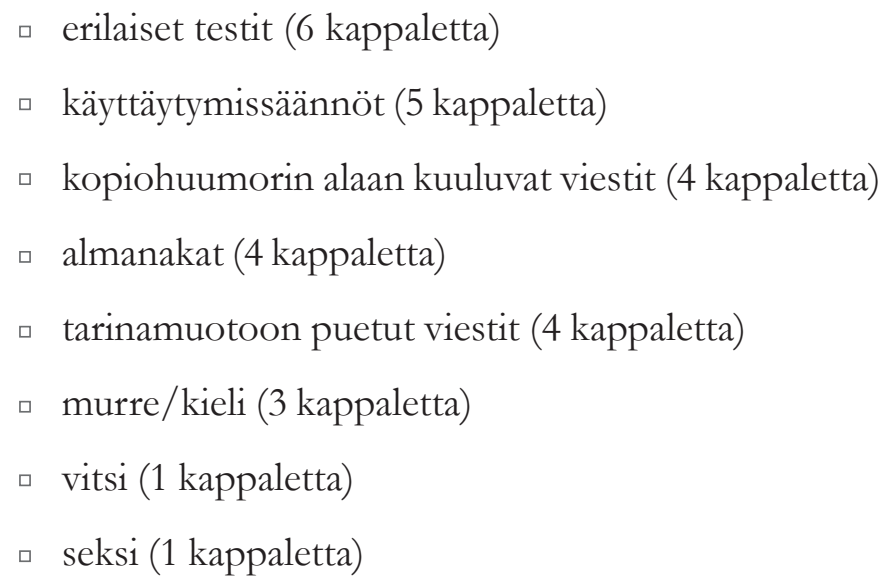

Testit ja käyttäytymissäännöt normittavat ja määrittävät suoraan eteläpohjalaisuutta. Esimerkkeinä eteläpohjalaisesta karnevalistisesta huumorista ne muodostavat yhdessä kopiohuumoriviestien ja almanakkojen kanssa kopiohuumorin sähköpostivastineet. Kopiohuumorista käy ilmi toimistohenkilöstölle läheiset esitysmuodot, kuten huoneentaulumaisuus ja lomakemuotoisuus. Toisaalta aineistossa ei esiintynyt lainkaan edellä mainittujen sisältöjen puhtaita muotoja. Viestien sisältökehysten aiheet olivat kahden suurimman luokan osalta luonteeltaan kontrolliin pyrkiviä. Eräs tulkinta tälle havainnolle on, että ilmiö toimii huumorin tehokeinona muodostaessaan vastinparin viestin muulle sisällölle. Vastaava havainto on tehty aiemmin sekä kopiohuumorin (Lipponen 1989) että sähköpostihuumorin (Aro 2003) tutkimusten kohdalla. Toisaalta yhteisöllisen identiteetin kohdalla kyse on aina tiettyjen sääntöjen ja normien mukaisesta olemistavasta.

Tutkimuksemme havainnot ovat suurelta osin samansuuntaisia aikaisempien pohjalaisuuden tulkintojen kanssa. Sosioemotionaalisessa sähköpostiviestinnässä alueelliset stereotypiat tuodaan esiin tietoisen performatiivisella ja leikittelevän humoristisella otteella (ks. myös. Sipilä 2002, 176; Knuuttila 1994). Äärimmäisiä piirteitä esitetään huumorin höysteellä sekä työteliäisyyden, itsenäisen yritteliäisyyden, toiminnallisuuden ja menestymisen kaltaisten hyvien ominaisuuksien että häjyilyn ja kateellisuuden kaltaisten heikkouksien osalta. Sähköpostiviestinnän huumorissa toistuva ironinen tyyli on olennaista myös alueen ihmisten 


\section{ETELÄPOHJALAISUUS SOSIOEMOTIONAALISESSA SÄHKÖPOSTIVIESTINNÄSSÄ}

mahtipontiselle puheelle ja uhoamiselle. Seppo Knuuttilan (1994, 86-91) mukaan itseen kohdistuvassa eteläpohjalaisessa huumorissa korostuvatkin tahtominen ja toiminnallisuus. Aineistoesimerkkinä tästä on "Kur moo tus" -viestin eli uusvanhan perushärmäläisen itsepuolustuslajin seitsemän kultaista sääntöä:

1) Anna aina vastustajan lyödä toisena.

2) Jokainen ihminen, jolla on vastenmielinen naamataulu, suunnittelee hyökkäystä. Sovella tällöin sääntöä yksi.

3) Toimi ensin, ajattele sitten.

4) Humalassa jokainen meistä voi päihittää kenet tahansa. Kannattaa ainakin yrittää.

5) Ei suuret sanat suuta halkaise. Älä siis turhaan hukkaa aikaa sovintoyrityksiin.

6) Pakoon lähteminen ei ole kiellettyä, mutta helvetinmoinen häpeä. Älä siis pakene.

7) Mitä enemmän nostat penkistä, sitä röyhkeämmin voit etuilla jonoissa. (Taulukko 1, kohdat 18-19.)

Uhoaminen ja oikeassa olemisen tarve, jotka herättävät väkivallan muodossa pelkoa myös pohjalaisissa itsessään, tulevat viesteissä esiin joko ohimennen tai huumorilla höystettyinä. Eteläpohjalaisuusuho on esillä viesteissä ja yhteiskunnallisesti hyväksyttävillä areenoilla eri tavoin, kuten omaisuuden keräämisenä ja sen kadehtimisena. Samoin eteläpohjalaisten uskonnollisuus näyttäisi taipuvan sosioemotionaalisessa sähköpostiviestinnässä yleiseksi persoonallisuuden piirteeksi, uskollisuudeksi ja ihmeiden ihmettelyksi. Isänmaallisuus oli muuntunut vastaavasti isäntämäisyyden erittelyiksi ja ulkomaalaisvitseiksi.

Kustaa Vilkunan $(1969,170)$ havaintojen mukaan paikallisihanteiden noudattamisesta peräisin oleva omaleimainen eteläpohjalainen luonne konkretisoituu erityisesti miehisessä kulttuurissa (rohkea, käskevä, voimakas, varakas, isosanainen, ei pelkäävä ja ihannoitu). Myös Riina Haanpää (2002; 2005) on tuonut tutkimuksissaan esiin eteläpohjalaisen luonteen maskuliinisuuden. Pohjalaisuuteen sisältyville kunnian, komeuden, miehisyyden ja voiman kulttuurisille piirteille sähköpostiviestintä onkin uusi ilmaisuväline, jossa stereotyyppisiä heimopiirteitä ylläpidetään.

Viestintävälineiden ja -kulttuurin muutos osoittaa, että historiallinen, sosiaalinen ja kulttuurinen eteläpohjalaisuus on muutoskykyinen kategoria. Sähköpostia hyödyntävä eteläpohjalainen kommunikaatio ylläpitää kokemuksellista alueellista identiteettiä mutta saattaa myös muuttaa joitain eteläpohjalaisuuteen liitettyjä sisällöllisiä tekijöitä. Sähköposti muiden muassa tuo eteläpohjalaisuuden kielteisiä piirteitä esiin positiivisella, huumoria hyväksikäyttävällä tavalla. (Ks. myös Zimmerbauer 2002, 60-74; Kulmala 2003, 146.) 
Kari Salo, Kaj Zimmerbauer, Timo Suutari

\section{SOSIOEMOTIONAALINEN SÄHKÖPOSTIVIESTINTÄ ETELÄPOHJALAISUUTTA LUOMASSA JA VAHVISTAMASSA}

Sähköpostiviestinnän voidaan tulkita rakentavan alueellista identiteettiä sekä prosessinomaisesti että viestien sisältöjen kautta. Prosessinomaisuus korostaa viestien lähettämisen sosiaalista ja verkostoja luovaa funktiota. Eteläpohjalaisuutta tuottavassa ja uusintavassa sähköpostiviestinnässä onkin kyse viestinnän rituaalimallista (Carey 1989), joka korostaa sekä merkitysten siirtämistä ja yhteyden luomisen prosessia että todellisuuden tuottamista ja ylläpitämistä. Rituaaliseksi määriteltynä viestintä ja kommunikaatio kytkeytyvät yhdessä jakamisen, osallistumisen, yhteenliittymisen, kumppanuuden ja yhteisen uskon käsitteisiin, jotka kuvaavat sosioemotionaalista sähköpostiviestintää. Viestien alueeseen liittyvät sisällöt puolestaan luovat osaltaan aluetietoisuutta sekä rakentavat ja uusintavat alueeseen liittyviä mielikuvia ja alueellista identiteettiä. Keskeistä on identiteetin mieltäminen sosiaalisena konstruktiona, jolloin sähköpostiviestien aluepuhunnan voidaan nähdä tuottavan maakuntaa huumorin keinoin ja stereotypioita uusintaen, samalla vahvistaen eteläpohjalaista henkeä. Stereotyyppiset eteläpohjalaisuuden merkit ja symbolit, kuten häjyily, lakeusmaisema ja "ittellisyys", olivat kaikki löydettävissä sähköisen viestinnän pääteemoina huumoria ja murretta hyödyntäen.

Aineisto antaa viitteitä siitä, että eteläpohjalaiseen kansanluonteeseen liittyy uudella ja aikaisemmasta poikkeavalla tavalla huumoria, mikä voidaan tulkita sosioemotionaalisen sähköpostiviestinnän mukanaan tuomaksi seikaksi. Eteläpohjalainen voi kertoa sähköpostin avulla itsestään ja arvostuksistaan, eikä viestiminen tapahdu yhtä vakavassa hengessä kuin "kylän raitilla" - josko se sielläkään vakavaa on ollut. Vakavat viestit ja teemat puuttuvat kokonaan. Kokonaisuudessaan voidaan todeta, että eteläpohjalaisuuteen sisällöllisesti liittyvät viestit ovat sopeutuneet humoristisen sosioemotionaalisen sähköpostiviestinnän päävirran mukaiseksi. Viestit voi tunnistaa esimerkiksi kopiohuumorin lähisukulaisiksi sen ohella, että ne tuottavat uudessa muodossa kuvaa (etelä)pohjalaisuudesta ja jatkavat näin osaltaan maakuntiin ja heimoidentiteetteihin liittyvää perinnettä.

Aiempia tutkimuksia sosioemotionaalisen sähköpostiviestinnän ja alueellisen identiteetin välisistä yhteyksistä ei ollut saatavilla, joten artikkelin löydöksien vertailu aiempiin tutkimustuloksiin ei ollut mahdollista. Alueellisen identiteetin näkökulmasta sosioemotionaalisilla sähköpostiviesteillä ja niiden liitetiedostoilla voidaan kuitenkin nähdä olevan merkityksiä eteläpohjalaisen identiteetin muotoutumisessa. Kotipaikkakunnalta muutto, juuriltaan etääntyminen, uuteen asuinpaikkaan kiinnittymisen ongelmat sekä irrallisuuden ja sitoutumattomuuden ilmiöt ovat luoneet tarpeita alueellisen identiteetin ilmentämiselle ja korostamiselle (ks. Heyes 2002; Miller \& Slatter 2000). Maakuntaan liittyvät sähköpostit vastaavat tähän tarpeeseen, vaikka niiden lähtökohtana onkin usein stereotypioiden ja symbolien ironisointi. Esimerkkejä uusien viestintävälineiden ja -tapojen käytöstä löytyy myös sähköisten viestimien ulkopuolelta muun muassa eri murrealueiden sarjakuvien muodossa. Samoin Etelä-Pohjanmaan lähettiläänä toimii Rehupiikles-bän- 


\section{ETELÄPOHJALAISUUS SOSIOEMOTIONAALISESSA SÄHKÖPOSTIVIESTINNÄSSÄ}

di, joka parodioi humoristisella otteella eteläpohjalaisia ilmiöitä ja tuo esiin paikallisesti sidottuja tarinoita. Eteläpohjalaisuus on esillä myös sanontojen ja piirroshahmojen muodossa muun muassa postikorteissa, sanomalehtien pilapiirroksissa ja kirjoissa.

Voidaan siis sanoa, että merkkien tuottaminen bitteinä ja viestien välittäminen sähköpostin avulla mahdollistaa alueellisen identiteetin ylläpitämisen: alueellisuudesta nouseva viestintä piirtää rajaa meidän ja muiden välille. Alueellisen samastumisen tarpeiden tyydyttäminen onnistuu nykyisin monin eri tavoin, esimerkiksi maakuntalehtien internetsivustoissa, maakuntaportaaleissa ja kuntien kotisivustossa. Voidaan kuitenkin ajatella, että yksittäisen toimijan näkökulmasta pelkästään surffailua edellyttävien passiivisten ja yksipuolisten tapojen sijaan sosioemotionaalinen sähköpostiviestintä tuottaa vahvemmin aluesamastumista, koska se on luonteeltaan tavoitteellista, vuorovaikutuksellista ja aktiivista.

Määrällisiä arvioita eteläpohjalaisuuteen liittyvästä sosioemotionaalisesta sähköpostiviestinnästä ja sen laajuudesta on mahdotonta esittää. Vaikka vertailevaa aineistoa ei olekaan käytössä, voidaan kuitenkin olettaa, että kyse ei ole mitenkään yksinomaan Etelä-Pohjanmaahan liittyvästä ilmiöstä. Myöskään eri mediaelementtien käytöstä sähköpostiviestinnässä ei ole saatavilla aiempaa tutkimustietoa, mutta aineistossamme eteläpohjalaisuus rakennetaan sähköpostiviestien sisällöissä lähinnä tekstuaalisin keinoin murretta hyödyntäen. Tarkasteltaessa sosioemotionaalisia sähköpostiviestejä kielen pintarakenteen näkökulmasta eteläpohjalainen "leviän" murteen käsite saa uusia ulottuvuuksia yltäessään yhä leveämmälle ja kauemmaksi internetin ja sähköpostin välityksellä.

Epävirallisen sosioemotionaalisen sähköpostiviestinnän suhde viralliseen, esimerkiksi maakuntaliiton strategiseen imagon tuottamisen on mielenkiintoinen. Molemmissa on kyse maakunnan kielellisestä tuottamisesta, vaikka retoriset keinot ovatkin kovin erilaisia. Nähtäväksi jää, omaksuuko virallinen imagopuhunta elementtejä epävirallisesta sähköpostiviestinnästä. Kenties nyt tutkitun kaltaista materiaalia hyödynnetään tulevaisuudessa. Ainakin tämän artikkelin aineisto voidaan nähdä digitaalisen kulttuurin arkistoimista vaativana osana.

Metodologisesti sähköpostitutkimus on monitieteistä ja vielä alkuvaiheessa. Tässä artikkelissa tehty kahden ilmiön, sosioemotionaalisen sähköpostiviestinnän ja alueellisen identiteetin, yhteyksien tarkastelu on luonteeltaan alustava, mutta osoittaa kuitenkin suuntaviivoja tulevalle tutkimukselle. Tulevalta tutkimukselta vaaditaan sekä syvyyttä että laajuutta niin aineiston kuin analyysinkin osalta. Diskursiiviset ja narratiiviset metodit sopivat hyvin sosioemotionaalisen sähköpostiviestinnän tutkimukseen ja ne rikastuttavat sähköpostiviestintää tai internetiä teknisesti lähestyvää tutkimusta. Erilaisten medioiden käyttötavat ja niiden sisältöjen tutkimus edellyttävät tietoyhteiskunnan tarkastelupohjan laajentamista pois puhtaasti teknisestä ajattelusta (vrt. Heinonen 2001, 10). 


\section{Kari Salo, Kaj Zimmerbauer, Timo Suutari}

\section{VIITTEET}

1. Nicholas Ducheneaut ja Leone Watts (2005, passim) jakavat sähköpostitutkimuksen kolmeen metaforilla nimeämäänsä teemaan. "Teknisesti orientoituvassa tiedostojen hallinta" -teemassa (file cabinet) keskeistä on informaation organisointi ja sähköpostiohjelmien hakutoiminnot. "Tuottavuusominaisuudet" -teemassa (production facility) keskitytään organisaatioviestinnän tehokkuuteen, joka on tyypillistä tietokoneavusteisen yhteistyön tutkimukselle. Kolmanneksi teemaksi eriytyy "kommunikaatiolaji" (communication genre), jota tutkimusta on tehty lähinnä organisaatiotutkimuksen ja informaatiosysteemien tutkimuksen parissa. Tässä yhteydessä kyse on ollut lähinnä sähköpostiviestinnän mukautuvuudesta ja soveltuvuudesta liikeviestintään. Käytännössä sähköpostiviestinnän sisältönä ovat olleet tekstimuotoiset viestit, mutta etenkin henkilökohtaisina viesteinä lähetetään nykyisin yhä enemmän erilaisia multimediaviestejä. Multimediaviestit sisältävät mediaelementtejä, kuten tekstejä, hypertekstejä, ääntä, valokuvia, grafiikkaa, animaatioita, videoleikkeitä, tietokantoja, online -interaktioita, html -sivustoja ja näiden erilaisia yhdistelmiä (ks. Luukkonen 2000). Multimediaviestit ovat lisääntyneet tietokoneiden, matkapuhelinten ja ohjelmistojen kehittymisen sekä voimakkaan markkinoinnin myötä.

2. Aron (2003) mukaan sähköpostihuumorin tehtävänä on huvittamisen ja ilahduttamisen ohella toimia faattisena viestintänä, jolla tarkoitetaan yhteyttä ylläpitävää viestinnän merkitystä. Aro erittelee tutkimuksessaan sähköpostihuumorin käytöskoodeja, sähköpostiviestin rakennetta, kansanperinneominaisuuksia ja sisältöaiheita. Hän päätyy pitämään sähköpostihuumoria omana perinteen lajina, uutta ja vanhaa sisältävänä ilmiönä, joka lainaa aineksia muusta kansanperinteestä sekä muodon että sisällön osalta.

3. Jako on säilyttänyt tutkimuksellisen käyttökelpoisuutensa (ks. Liu 2002), ja se vastaa työstressin hallintakeinojen (coping) perusjaottelua ongelmakeskeisiin ja emotionaalis-palliatiivisiin keinoihin, joilla helpotetaan omaa oloa (ks. Salo 2002).

4. Tämän artikkelin tausta-aineistona on 520 sosioemotionaalista sähköpostiviestiä. Työ- ja opiskeluorganisaatioiden sähköpostijärjestelmistä lähetettiin 82 prosenttia (428) viesteistä, ja 18 prosenttia (92) lähettäjistä käytti henkilökohtaista sähköpostiosoitettaan. Vastaavasti 79 prosenttia (411) viesteistä lähetettiin virka-aikana eli klo 8-17 välillä ja 21 prosenttia (109) sen ulkopuolella.

5. Sähköisen viestinnän välineet mahdollistavat uudenlaisia yhteisöllisyyden muotoja, jotka ovat kiinnostaneet myös tutkijoita. Tutkimuksellisena lähtökohtana ovat toimineet muun muassa uudet mediat ja näiden ympärille muodostuneet yhteenliittymät. Esimerkiksi Nancy K. Baym (2002) on eritellyt tutkimuksissaan saippuaoopperan ympärille muodostunutta virtuaalista uusyhteisöä. Barry Wellman (2001) puolestaan painottaa, että viestintävälineestä huolimatta itse verkosto muodostuu ihmisistä ja sähköisen viestinnän ydin on aina inhimillinen ja so- 


\section{ETELÄPOHJALAISUUS SOSIOEMOTIONAALISESSA SÄHKÖPOSTIVIESTINNÄSSÄ}

siaalinen. Barry Wellmanin (1997, 2001) ja Manuel Castellsin (2000) mukaan tietokoneverkostot ovatkin luonnolliselta olemukseltaan sosiaalisia verkostoja, jotka linkittävät ihmisiä, organisaatioita ja tietoa.

6. Tutkimusaineisto koostuu henkilökohtaisista sähköpostiviesteistä, joiden analysoinnissa lähtökohtana ollut anonyymiys ja sisältölähtöisyys jatkuivat läpi analysointi- ja julkaisuprosessin. Aineiston voidaan myös kokonaisuudessaan nähdä koostuvan roskapostiviesteistä (vrt. Savinen 2004), mutta artikkeliin valitun näkökulman lähtökohta on viestinnällinen ja pyrkii olemaan neutraali. Rajallinen sähköpostiviestintäaineisto mahdollistaa sen esittämisen elektronisesti jaeltavassa artikkelissa kokonaisuudessaan, mistä seuraavan läpinäkyvyyden myötä lukijan on helppo arvioida tutkimusta kokonaisuudessaan (Taulukko 1). Käytännössä tutkimusaineiston analyysi oli kvalitatiivista luonteeltaan kohdentuen sisällöllisiin ilmiöihin valittujen näkökulmien suuntaisesti. Käytännön kirjoittamistyön myötä aineistosta tehtyjä havaintoja reflektoitiin ryhmätyönä, jolloin kirjoittajien edustamat eri tieteenalojen näkökulmat ja käsitteet tulivat analysoinnissa esiin.

\section{TutKIMUSAINEISTOT}

Tutkimusaineisto muodostuu tutkija Kari Salon vastaanottamista sähköpostiviesteistä, sekä näiden viestien sisältämistä tiedostoista ja viesteihin linkitetyistä internet -sivustoista (ks. Taulukko 1). Aineisto on tekijän hallussa.

\section{Seminaariesitelmät:}

TIETOYHTEISKUNNAN PELISÄÄNNÖT JA YKSITYISYYS -SEMINAARI [online]. <http://www.soberit.hut.fi/netprivacy/hanasaari/> [19.09.2005.] AARNIO, REIJO 2004: Tietoyhteiskunnan pelisäännöt ja yksityisyys. -Tietoybteiskunnan pelisäännötja ykesityisyys -seminaari, 20.-21.1.2004. Helsinki, Säätytalo. HARJUHAHTO-MADETOJA, KATRINA 2004: Hallituksen tietoyhteiskuntaohjelma - yksityisyydensuoja ja tietoturva. - Tietoybteiskunnan pelisäännöt ja yksityisyys -seminaari, 20.-21.1.2004. Helsinki, Säätytalo.

WALLIN, ANNA-RIITTA 2004: Henkilötietolaki ja muu informaatio-oikeudellinen sääntely. - Tietoyhteiskunnan pelisäännöt ja yksityisyys -seminaari, 20.-21.1.2004. Helsinki, Säätytalo.

\section{KiRjallisuUs}

ARO, JARI 2003: 'Mitä yhteistä on miehillä ja sukkahousuilla?” Huomioita sähköposti-huumorista. - Mediumi 2.2 Teemanumero internet on... [online]. <http:// www.m-cult.net/mediumi/> [13.09.2005.] 
BARNES, TREVOR J. \& DUNCAN, JAMES S. (eds.) 1992: Writing Worlds. Discourse, Text and Metaphor in the Representation of Landscape. London: Routledge.

BAYM, NANCY K. 2002: Interpersonal Life Online. - Lievrouw, Leah A. \& Livingstone, Sonia (eds.), Handbook of New Media. Social Shaping and Consequences of ICTs. London: Sage Publications.

CAREY, JAMES 1989: Communication as a Culture: Essays on Media and Society. New York: Routledge.

CASTELLS, MANUEL 2000: Rise of the Network Society. Oxford: Blackwell.

D-FENCE OY:N TILASTOT 2005: [online]. < http://www.d-fence.fi/statistiikka> [13.09.2005.]

DUCHENEAUT, NICHOLAS \& WATTS, LEON A. 2005: In Search of Coherence: A Review of E-mail Research. - Human-Computer Interaction 20: 11-48. FLYNN, NANCY \& RANDOLPH, KAHN 2003: E-mail rules. A Business Guide to Managing Policies, Security, and Legal Issues for E-Mail and Digital Communication. New York: Amacom.

HAANPÄ̈̈, RIINA 2002: Pukkilan Jaska ja murha. - Elore (9)1. [online]. <http:/ /cc.joensuu.fi/ loristi/1_02/haa102.html> [13.09.2005.]

- 2005: Velisurmasta suvun muistoksi. - Elore 12(1) [online]. <http:// cc.joensuu.fi/ loristi/1_05/haa1_05.pdf > [13.09.2005.]

HALLITUKSEN ESITYS EDUSKUNNALLE LAIKSI YKSITYISYYDEN SUOJASTA TYÖELÄMÄSSÄ JA ERÄIDEN SIIHEN LIIT'TYVIEN LAKIEN MUUT'TAMISESTA. HE 162/2003 vp. [online]. <http://www.finlex.fi/fi/esitykset/he/2003/20030162> [13.09.2005.]

HEINONEN, ARI 2001: Introduction: The Global Net, Locality Publicness. - Heinonen, Ari \& Mäkinen, Maarit \& Ridell, Seija \& Martikainen, Ari \& Halttu, Mika \& Sirkkunen, Esa (eds.), Locality in the Global Net. The Internet as a Space of Citizen Communication and Local Publicness. Department of Journalism and Mass Communication, Publications. Series C 33. Tampere: University of Tampere.

HEYES, CRESSIDA 2002: Identity Politics. - Stanford Encyclopedia of Philosophy. [online]. <http://plato.stanford.edu/entries/identity-politics/\#9> [24.10.2005.] HÄKLI, JOUNI 1994: Maakunta, tieto ja valta. Tampere: Tampereen yliopisto.

HÄNNINEN, SAKARI 1998: Johdanto. - Hänninen, Sakari (toim.), Missä on tässä? Yhteiskuntatieteiden, valtio-opin ja filosofian julkaisuja 18. Jyväskylä: Jyväskylän yliopisto.

KANSALLISET TIETOTURVATALKOOT 2005 [online]. <http:// www.tietoturvaopas.fi/ajankohtaista/tietoturvatalkoot.html $>$ [19.09.2005.]

KAUNISMAA, PEKKA 1997a: Mitä on kollektiivinen identiteetti? - Virtapohja, Kalle (toim.), Puheenvuoroja identiteetistä. Johdatusta ybteisöllisyyden ymmärtämiseen. Jyväskylä: Atena.

— 1997b: Keitä me olemme? Kollektiivisen identiteetin käsitteellisistä lähtökohdista. - Sosiologia 34(3): 220-230.

KINNUNEN, AARNE 1994: Huumorin ja koomisen keskeneräinen kysymys. Porvoo: WSOY. 


\section{ETELÄPOHJALAISUUS SOSIOEMOTIONAALISESSA SÄHKÖPOSTIVIESTINNÄSSÄ}

KIVISTÖ, KALEVI 1997: Kuinka käy keskisuomalaisuuden? - Virtapohja, Kalle (toim.), Puheenvuoroja identiteetistä. Johdatusta yhteisöllisyyden ymmärtämiseen. Jyväskylä: Atena.

KNUUTTILA, SEPPO 1992: Kansanhuumorin mieli. Kaskut maailmankuvan aineksena. Suomalaisen Kirjallisuuden Seuran Toimituksia 554. Helsinki: Suomalaisen Kirjallisuuden Seura.

— 1994: Tyhmän kansan teoria. Näkökulmia menneestä tulevaan. Tietolipas 129. Helsinki: Suomalaisen Kirjallisuuden Seura.

KULMALA, MARKKU 2003: Miss' laaja ankee? Antti Tuurin Pobjanmaa-sarjan merkitysrakenteita. Acta Universitatis Tamperensis 975. Tampere: Tampereen yliopisto.

LEPPÄLAHTI, MERJA 2002: Naurua pelissä. - Elore (9)1. [online]. <http:// cc.joensuu.fi/ loristi/1_02/lep102.html> [24.10.2005.]

LIPPONEN, ULLA (toim.) 1989: Sïstiä sisätyötä: kopiobuumoria. Helsinki: Suomalaisen Kirjallisuuden Seura.

LIU, YULIANG 2002: What Does Research Say about Nature of Computer-Mediated Communication: Task-Oriented, Social-Emotion-Oriented, Or Both? - Electronic Journal of Sociology 6(1), April [online]. <http://www.sociology.org/ content/vol006.001/liu.html> [13.09.2005.]

LUUKKONEN, JUSSI 2000: Digitaalisen median käsikirjoitusopas. Helsinki, Edita. MILLER, DANIEL \& SLATER, DON 2000: Internet: An Ethnographic Approach. Oxford: Berg Publishers.

NURMELA, JUHA \& SIRKIÄ, TIMO 2004: Muistio tietoybteiskuntaobjelmalle suomalaisten tieto-ja viestintätekniikean käytöstä ja sïhen subtautumisesta marraskunssa 2004.

- Tilastokeskus. Haastattelu- ja tutkimuspalvelut. [online]. <http://www.valtioneuvosto.fi/tiedostot/pdf/fi/92025.pdf> [24.10.2005.]

PAASI, ANSSI 1986: Neljä maakuntaa. Maantieteellinen tutkimus aluetietoisunden kehittymisestä. Joensuu: Joensuun yliopisto.

PYÖRIÄ, PASI 2001: Hajautettu työ. - Blom, Raimo \& Melin, Harri \& Pyöriä, Pasi (toim.), Tietotyö ja työelämän muntos. Palkkatyön arki tietoybteiskunnassa. Helsinki: Gaudeamus.

REICH, ROBERT 1995: Rajaton maailma. Yritysten ja kansallisvaltioiden undetpelisäännöt. Helsinki: Suomen itsenäisyyden juhlarahasto; Espoo: Trantex-kustannus.

SALO, KARI 2002: Teacher Stress as a Longitudinal Process. Jyväskylä Studies in Education, Psychology and Social Research, 208. Jyväskylä: University of Jyväskylä.

SAVINEN, JARNO 2004: Roskaposti. Säbköisen viestinnän kasvava ubka. Mediakulttuurin julkaisuja No. 2/2004. Joensuu: Joensuun yliopisto, Mediakulttuurin keskus.

SAVOLAINEN, VELI-ANT'TI 1995: Huominen on tänään - yhteenveto tietoyhteiskunnasta. - Savolainen, Veli-Antti \& Himanen, Pekka (toim.), Kobtaamisyhteiskunta. Kirja mabdollisundesta. Helsinki: Edita, 11-28.

SIPILÄ, JUHANI 2002: Maa luja, taivas korkia. Antti Tuurin Pohjanmaa-sarja. Helsinki: Otava. 
SPROULL, LEE \& KIESLER, SARA 1986: Reducing Social Context Cues: Electronic Mail in Organizational Communication. - Management Science 32: 1492-1512.

STEINFIELD, CHARLES W. 1985: Dimensions of Electronic Mail Use in Organizations. - Academy of Management Journal1985: 239-243.

- 1986: Computer Mediated Communication in an Organizational setting: Explaining Task-Related and Socioemotional Uses. - MCLAUGHLIN, M. (ed.), Communication Yearbook 9. Beverley Hills, CA: Sage.

TALVITIE, JUHA 2000: Kunta vai maakunta? Globalisaatio ja regionalismi. Polemia-sarjan julkaisu nro 36. Helsinki: Kunnallisalan kehittämissäätiö.

TIETOYHTEISKUNTAOHJELMA 2005 [online]. <http://www.tietoyhteiskuntaohjelma.fi/fi_FI/> [19.09.2005.]

VIESTINTÄVIRASTO, CERT-FI Ohje 3/2003. Roskapostituksen aiheuttamat ongelmat. [online]. <http://www.ficora.fi/suomi/tietoturva/ohjeet/ohje-200303.htm $>$ [24.10.2005.]

VILKUNA, KUSTAA 1969: Kansantaide ja perinnepolitiikeka: Kansantaiteen seminaari Seinäjoella 10.6.-15.6.1968. Helsinki: Suomen Kulttuurirahasto.

VÄHÄMÄKI, JUSSI 2004: Kuhnurien kerho. Vanhan työn paheista unden byveiksi. Helsinki: Tutkijaliitto.

WELLMAN, BARRY 1997: An Electronic Group is Virtually a Social Network. - Kiesler, Sara (ed.), Culture of the Internet. Mahwah, N.J.: Lawrence Erlbaum Associates, Publishers.

- 2001: Computer Networks As Social Networks. - Science 293(14): 2031-2034.

WHITTAKER, STEVE, BELLOT'TI, VICTORIA \& MOODY, PAUL 200 5: Introduction to This Special Issue on Revisiting and Reinventing Email. - Special Issue of Human-Computer Interaction 2005: 1-2.

YLÖNEN, MARJA 1995: Karin suomalainen. Pilapiïrokset suomalaisunden legitimointina. Acta Universitatis Tamperensis, ser A vol. 468. Tampere: Tampereen yliopisto, ZIMMERBAUER, KAJ 2002: Etelä-Pohjanmaan imago. Maakunnallisten mielikuvien jälilllä. Seinäjoki: Helsingin yliopisto, Maaseudun tutkimus- ja koulutuskeskus.

FT, YTM, KM Kari Salo toimii yliopettajana Seinäjoen ammattikorkeakoulun kulttuurinalan ja muotoilun yksikössä ja valmistelee sosioemotionaaliseen sähköpostiviestintään liittyvää sosiologian väitöskirjaa.

FM Kaj Zimmerbauer toimii tutkijana Helsingin yliopiston Ruralia-instituutin Seinäjoen yksikössä ja valmistelee alueelliseen imagoon ja identiteettiin liittyvää maantieteen väitöskirjaa.

HTM Timo Suutari toimii tutkijana Helsingin yliopiston Ruralia-instituutin Seinäjoen yksikössä ja on työssään tarkastellut kulttuurin ja aluekehityksen välisiä yhteyksiä. 